\section{Evaluation of physiological characteristics of curcuma (Curcuma xanthorhizha Roxb.) on various intercropping patterns with soybean [Gglycine max (L.) Merrill]}

\author{
Ellis Nihayati, Deffi Armita, \\ Binti Rulliyah
}

Department of Agronomy, University of Brawijaya, Malang, Indonesia

\begin{abstract}
s
Purpose of this research was to get the best planting pattern on Curcuma (Curcuma xanthorrhiza Roxb. Synm. Curcuma javanica) and soybean (Glycine max (L.) Merrill) related to plants production, land equivalent ratio (LER) and $\mathrm{R} / \mathrm{C}$ ratio. This research used the randomized block design involving six treatments and four replications. The growth pattern and yield of curcuma were based on the following parameters: length of plant, number of leaf, broad of leaf, fresh and dry weight of leaves, curcuma root and rhizome, LER (land equivalent ratio) and $\mathrm{R} / \mathrm{C}$ ratio within six months from December 2015 to June 2016. The treatment difference was based on the LSD5\%. The result showed that curcuma planted one month earlier under narrow spacing and bigger soybean population (strip relay, T-K)) suggested a longer growth than any other plating patterns. On the contrary, curcuma planted one month earlier under wide spacing and fewer number of soybean plants (row relay, T-K) suggested a better growth than others and resulting in the highest curcuma yield, lower soybean yield, LER $=1.09$ dan $\mathrm{R} / \mathrm{C}=2.36$.
\end{abstract}

\section{Introduction}

Temulawak or curcuma (Curcuma xanthorrhiza Roxb. Synm. Curcuma javanica) is one of medicinal plants from Zingiberaceae family which has high potential to be developed as medicine. ${ }^{1-4}$ The using of curcuma as traditional herbal medicine has reached 3000 tons of dried rhizomes a year. ${ }^{5}$ It can be concluded from these large need of curcuma raw materials that this plant suggests a high potency to be cultivated. But it is still constrained by the limited raw material in quantity and quality rhizome of temulawak. There are secondary metabolites in curcuma rhizome, ${ }^{6-8}$ some have antibacterial activities, ${ }^{9}$ and allelopathy effects on surrounding plants.

In addition, the curcuma plant has a long harvest period (10-12 months) and wide row spacing $(50 \times 100 \mathrm{~cm})$ causing farmers are reluctant to plant it as the main crop. Intercropping between curcuma and food plants is a solution that can be used. One of the right intercropping is between curcuma and soybean because the soybean crop has a shorter period (115 days) as well as having a narrow row spacing of $20 \times 30$ $\mathrm{cm}, 30 \times 30 \mathrm{~cm}$ or $40 \times 10 \mathrm{~cm}$. Intercropping between root crops, including curcuma, with other plants can add economic benefit, which is expected to attract farmers to cultivate curcuma, both as a main-crop or intercrops. $^{9-15}$

This study aimed to analyze physiological characteristics changes of curcuma intercropped with soybean at different planting patterns.

\section{Materials and Methods}

This research was conducted at Faculty of Agriculture experiments field in Jatikerto village, Malang, Indonesia (altitude of 350 $\mathrm{m}$ asl, temperature of $27^{\circ} \mathrm{C}$, rainfall of 120 $\mathrm{mm} / \mathrm{month}$ ), University of Brawijaya's Physiology Laboratory. This study was conducted in six months from December 2015 to June 2016. The tools used in this research wereoven, rough and analytical scales, while the material used were the rhizome of curcuma UB2, Willis soybean seed varieties, SP36 fertilizer, $\mathrm{KCl}$ and urea.

This study used a randomized block design (RAK) consisting of 6 treatments and 4 replications. Those treatments were; row cropping (T1), strip cropping (T2), row relay soybean planting one-month after curcuma (T3), strip relay soybean planting one-month after curcuma (T4), row relay planting curcuma one month after soybean (T5) and relay planting strips of curcuma one month after soybeans (T6). Monoculture is used as a comparison in the calculation of LER and $\mathrm{R} / \mathrm{C}$ ratio.

Observations were carried out in destructive to determine the pattern of growth of plants covering length $(\mathrm{cm})$, number of leaves (leaf) and leaf area $\left(\mathrm{cm}^{2}\right)$ on the curcuma plant. While on the soybean was the plant height $(\mathrm{cm})$, number of leaves (leaf) and leaf area $\left(\mathrm{cm}^{2}\right)$, and nondestructive A non-destructive observation (harvest) includes the weight of fresh and dry leaves, roots and rhizomes (g) per plant on curcuma plants, while on the soybean plants include fresh weight and dry stover (g), pods (beans), pods weight $(\mathrm{g})$, weight and dry beans and weight of 100 seeds $(\mathrm{g})$.
Correspondence: Ellis Nihayati, Department of Agronomy, Faculty of Agriculture, University of Brawijaya, Malang, East Java, Indonesia.

E-mail: nihayati53@yahoo.com

Key words: curcuma; soybean; intercropping pattern; LER.

Acknowledgements: the authors deeply acknowledged Nur Azizah, Wisnu Eko Murdiono, and Sitawati who have helped this research; and Ministry of Research Technology and Higher Education (RISTEKDIKTI) for the Operational Support Program for State Universities (BOPTN) UB 2015

Contributions: the authors contributed equally

Conflict of interest: the authors declare no potential conflict of interest.

Received for publication: 23 September 2016. Accepted for publication: 10 November 2016.

This work is licensed under a Creative Commons Attribution-NonCommercial 4.0 International License (CC BY-NC 4.0).

(C) Copyright E. Nihayati et al., 2017

Licensee PAGEPress srl, Italy

International Journal of Plant Biology 2017; 8:6905 doi:10.4081/pb.2017.6905

Analysis of data using analysis of variance (ANOVA) to examine the effect of treatment on the data of growth and yield parameters with soybean. In the event of a real influence on the treatment, the real difference test using LSD5\%.

\section{Results and Discussion}

Analysis of variance showed that intercropping systems between curcuma and soybean suggest the significant effects on growth and yield of curcuma and soybeans.

\section{Curcuma plant growth and yield}

Curcuma plants that were planted one month after the soybean had a lower height or depressed compared to those of one months earlier or those at the same time (Figure 1). This was caused by time differences in planting of both crops that affected vegetative growth and generative plant. ${ }^{16}$ The lenght of curcuma plants with strip relay T-K cropping pattern showed a higher value than other pattern (Table 1), where in that cropping pattern,curcuma planted one month earlier, narrow spacing and more soybean population. They resulted curcuma 
and soy crops competed in getting sunlight.

The number of leaves, leaf area and high curcuma shoots were shown in row relay $\mathrm{T}-\mathrm{K}$ cropping patterns where curcuma were planted one month earlier, wide row spacingand less soybean population. In addition, the row relay $\mathrm{T}-\mathrm{K}$ cropping pattern also had a higher leaf weight than other cropping patterns (Table 2). The bigger number of leaves and wider leaf area will be directly proportional to the weight of the leaves,this was in accordance with the results of rhizome wet and dry weight in high error relay T-K of cropping pattern that others were $1394.5 \mathrm{~g} / \mathrm{plant}$ and 177.8 $\mathrm{g} /$ plant. Curcuma plants which were planted early (1 month) were suspected to dominate the growth space and adapt to the environment. ${ }^{17-19}$ Furthermore, the wide spacing and less number of soybean population on row relay $\mathrm{T}-\mathrm{K}$ cropping pattern were allegedly able to reduce the competition between curcuma plant and soybean in getting growth factors such as sunlight, plant nutrients, $\mathrm{CO} 2$ and air circulation. ${ }^{20-23}$

Soybean plants with strip relay K-T cropping patterns where the soybean crops were planted one month earlier, with narrow row spacing and more soybean population had higher number of soybean leaf, wider leaf and more pod number higher than other cropping patterns. In accordance with the revelation of Sakya et al. ${ }^{24}$ the higher plant is, the more leaves and lush book will be. As a result there were more pods produced.A higher vegetative growth on strip relay $\mathrm{K}-\mathrm{T}$ cropping patterns causing the growth of curcuma plants suppressed affecting the rhizome production became lower than other cropping patterns (Table 3 and Figure 2). This is presumably because the curcuma plants were not able to pass the critical phase as well as the soybean crop had mastered the grow space early. Critical phases of crop occur at the age of $1 / 4$ or $1 / 3$ to $1 / 2$ the age of the plant, so at the age of plant growth factor requirements must be met. ${ }^{27}$ Production is the main result component of the cultivation system. The higher result of curcuma obtained from row relay T-K pattern was 89.25 tons ha $^{-1}$ followed by strip relay T-K pattern was 83.20 tons $\mathrm{ha}^{-1}$ (Table 3 and Figure 2), where on those cropping patterns the curcuma plants were planted one month earlier than the soybean plants, although statistically, it was not significantly different with ones planted at the same time. High yield in the row relay T-K cropping pattern and strip relay $\mathrm{T}-\mathrm{K}$ allegedly because curcuma plants were able to compete in getting growth factors so that higher growth and photosynthates were translocated in storage organs (rhizomes) more. In contrast, soybean crops were planted with row relay T-K cropping patterns and strip relay T-K had a low production yield of 0.75 tons $\mathrm{ha}^{-1}$ and 2:06 ton ha $^{-1}$ (Figure 3).
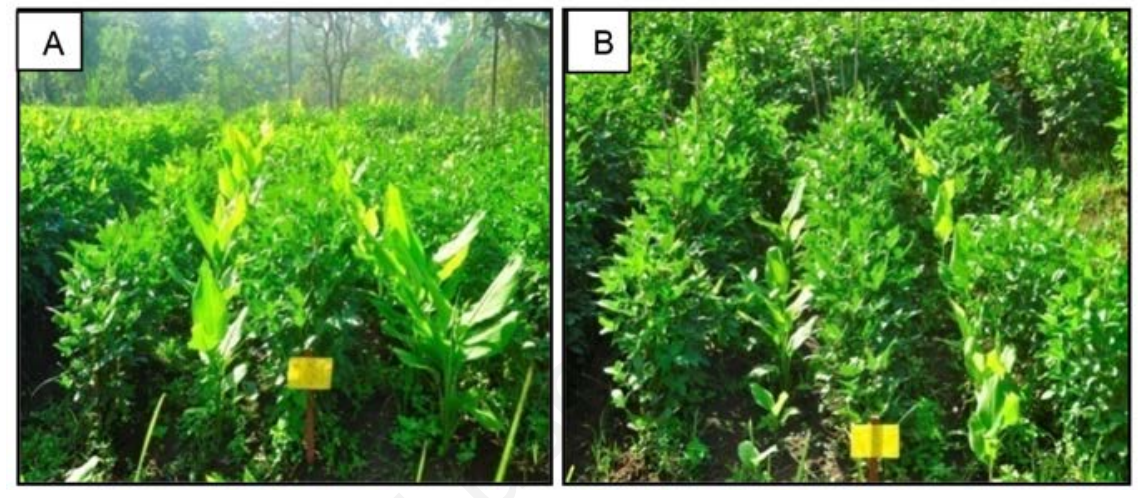

Figure 1. A) Row Relay Curcuma 12 WAP (weeks after planting) and Soybean WAP, B) Row Relay Soybean 12 WAP (weeks after planting) and Curcuma 8 WAP (B).

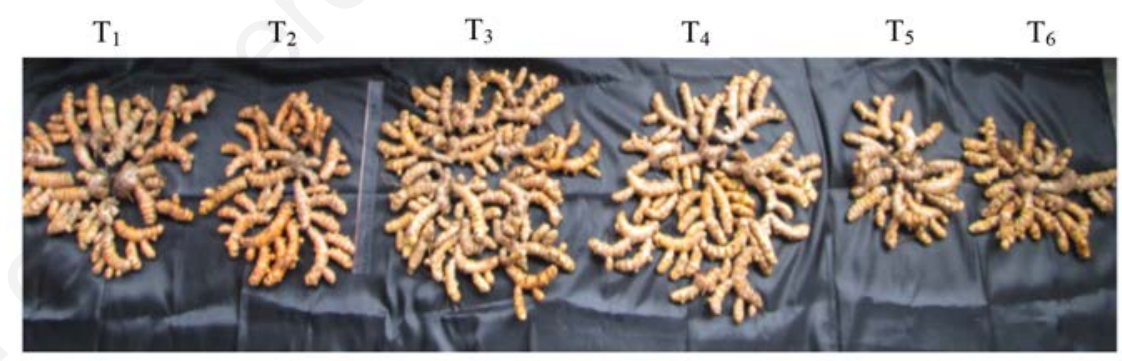

Figure 2. Fresh Curcuma Rhizome at Age 24 WAP on the Different Treatment cropping pattern T1 row cropping, T2 strip cropping, T3 row relay (T-K), T4 strip relay (T-K), T5 row relay $(K-T)$ and $T 6$ strip relay $(K-T) . T=$ curcuma plant, $K=$ soybean plants.

Table 1. Lenght of curcuma plants on different cropping pattern.

\begin{tabular}{lcccccccc} 
Cropping pattern treatment & \multicolumn{5}{c}{$\begin{array}{c}\text { Lenght of plant (cm) } \\
\end{array}$} & \multicolumn{7}{c}{ Observation time (week after planting) } \\
& 4 & 6 & 8 & 10 & 12 & 14 & 16 \\
T1 = Row cropping & $16.35^{\mathrm{ab}}$ & $27.40^{\mathrm{ab}}$ & $53.60^{\mathrm{ab}}$ & $72.25 \mathrm{~cd}$ & $87.95 \mathrm{~cd}$ & $94.10^{\mathrm{b}} \mathrm{c}$ & $98.35^{\mathrm{b}}$ & $101.25 \mathrm{c}$ \\
T2 = Strip cropping & $14.67^{\mathrm{a}}$ & $32.72^{\mathrm{ab}}$ & $64.75^{\mathrm{b}}$ & $89.75 \mathrm{e}$ & $96.07 \mathrm{~cd}$ & $100.00 \mathrm{c}$ & $102.07^{\mathrm{b}} \mathrm{c}$ & $105.07 \mathrm{c}$ \\
\hline T3 = Row relay (T-K) & $24.32^{\mathrm{bc}}$ & $38.67^{\mathrm{bc}}$ & $55.00^{\mathrm{ab}}$ & $69.17^{\mathrm{b}} \mathrm{c}$ & $84.42^{\mathrm{b}} \mathrm{c}$ & $94.92^{\mathrm{b}} \mathrm{c}$ & $103.02^{\mathrm{b}} \mathrm{c}$ & $105.20 \mathrm{c}$ \\
T4 = Strip relay (T-K) & $28.25^{\mathrm{c}}$ & $47.00^{\mathrm{c}}$ & $65.90^{\mathrm{b}}$ & $81.07 \mathrm{de}$ & $97.32 \mathrm{~d}$ & $103.90 \mathrm{c}$ & $109.57 \mathrm{c}$ & $115.67 \mathrm{~d}$ \\
\hline T5 = Row relay (K-T) & $16.07^{\mathrm{a}}$ & $24.75^{\mathrm{a}}$ & $42.00^{\mathrm{a}}$ & $52.42^{\mathrm{a}}$ & $62.50^{\mathrm{a}}$ & $74.50^{\mathrm{a}}$ & $75.57^{\mathrm{a}}$ & $76.00^{\mathrm{a}}$ \\
T6 = Strip relay (K-T) & $14.82^{\mathrm{a}}$ & $26.80^{\mathrm{ab}}$ & $44.00^{\mathrm{a}}$ & $61.05^{\mathrm{ab}}$ & $75.65^{\mathrm{b}}$ & $85.85^{\mathrm{b}}$ & $86.10^{\mathrm{a}}$ & $86.60^{\mathrm{b}}$ \\
\hline LSD 5\% & 8.14 & 11.41 & 13.55 & 11.06 & 12.14 & 11.11 & 10.58 & 10.43 \\
CV (\%) & 28.33 & 23.03 & 16.60 & 10.35 & 9.59 & 8.00 & 7.33 & 7.04 \\
\hline
\end{tabular}

Values followed by the same letters in the same column on each treatment showed no significant difference influence by LSD5\%. $\mathrm{T}=$ Curcuma plant, $\mathrm{K}=$ soybean plants. 
The production results will affect the crop yield in unit area. For instance, to get high soybean crop yields with strip relay K$\mathrm{T}$ cropping patterns was 5.67 ton $\mathrm{ha}^{-1}$ and with the strip cropping was 4.90 ton $\mathrm{ha}^{-1}$ of dry soybeans. The strip cropping pattern has more population of soybean so that soybeans yields on harvest unit area are also more even though the yield per plant is lower. ${ }^{25-27}$ reported that number of plants per unit area is an important factor to get high yields. ${ }^{28}$ Wide spacing can increase the yield of eachcrop; otherwise narrow spacing and bigger population would increase the competition between plants to get growth factor. It has been showed that sweet potato crops grown with strip cropping patterns got 14.53 tons $\mathrm{ha}^{-1}$, and on row cropping pattern was 6.20 ton $\mathrm{ha}^{-1}$ where the sweet potato crop with strip cropping pattern was bigger than row cropping patterns.

Land ratio showed that strip cropping pattern produced a higher value than other cropping patterns which was 1.5 , but not significantly different with strip relay $\mathrm{T}-\mathrm{K}$ cropping patterns. The next high equality ratio of land shown by the following cropping pattern; strip relay $\mathrm{K}-\mathrm{T}$, row relay $\mathrm{T}-\mathrm{K}$ and row cropping (Table 4). They were considered advantageous in land use efficiency because the score was more than one. Stripcropping pattern showed a higher land equality ratio because the curcuma and soybean productions were higher than than any other patterns, so that when divided by monoculture the value generated was also high. Equivalence ratio for all intercropping types is more than one means that intercropping cultivation is more profitable than monoculture. $^{29}$

The result of the $\mathrm{R} / \mathrm{C}$ ratio calculation was known that almost all of the cropping pattern could be developed, except for row cropping K-T and strip cropping K-T patterns because those cropping pattern had the $\mathrm{R} / \mathrm{C}$ ratio $<1$, namely 0.93 and 0.94 (Table $5)$. In the further analyzes, row cropping, strip cropping, row relay $\mathrm{T}-\mathrm{K}$ and strip relay $\mathrm{T}-\mathrm{K}$ patterns should be developed and the highest profit gained from row relay $\mathrm{T}-\mathrm{K}$ planting patterns was IDR 183,130,000.00 to $\mathrm{R} / \mathrm{C}$ ratio of 2.36 . It was assumed that because of curcuma production with T3 patterns was also higher than other cropping patterns at 89.25 tons $\mathrm{ha}^{-1}$, although soybean production was lower at 0.75 tons $\mathrm{ha}^{-1}$. The lower soybean production in row relay $\mathrm{T}-\mathrm{K}$ pattern was caused by the less of soybean population compare to those cultivated in monoculture so that the yield per unit area was also lower.

\section{Conclusions}

Intercropping of curcuma and soybean plants could increase total productivity of curcuma and soybeans. In row relay T-K cropping patterns, curcuma plants generated growth and yield parameters as well as higher per-unit area yield than other cropping pattern, so as to produce higher $\mathrm{LER}=1.09$ and $\mathrm{R} / \mathrm{C}$ ratio $=2.36$ than other cropping patterns.

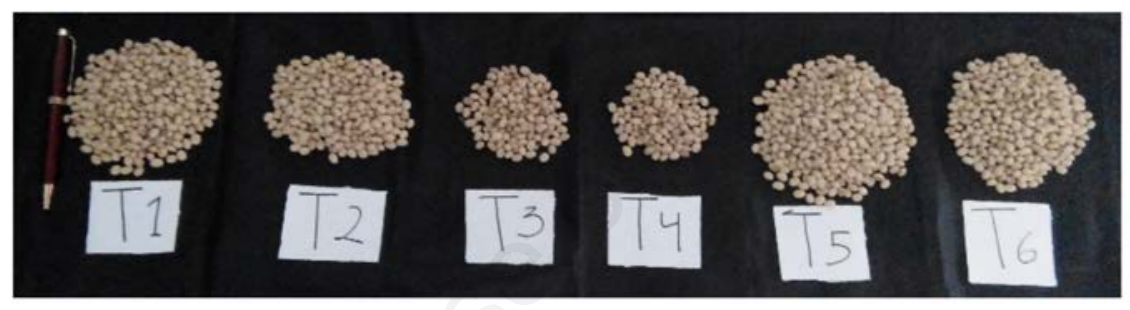

Figure 3. Soybean dried seed per plant Aged 14 WAP on different cropping pattern treatment: $\mathrm{T} 1$ row cropping, $\mathrm{T} 2$ strip cropping, $\mathrm{T} 3$ row relay (TK), T4 strip relay (TK), T5 row relay $(\mathrm{KT})$ and $\mathrm{T} 6$ strip relay $(\mathrm{KT}), \mathrm{T}$ = curcuma plants, $\mathrm{K}=$ soybean plants.

Table 2. Fresh and dry weight of curcuma leaves on various cropping patterns.

\begin{tabular}{lcc} 
Cropping pattern & Fresh weight of leaves (g/plant) & Dry weight of leaves (g/plant) \\
T1 = Row cropping & $728.67^{\mathrm{bc}}$ & $95.55^{\mathrm{b}}$ \\
$\mathrm{T} 2$ = Strip cropping & $598.62^{\mathrm{b}}$ & $84.85^{\mathrm{bc}}$ \\
\hline $\mathrm{T} 3$ = Row relay (T-K) & $1032.07^{\mathrm{d}}$ & $122.97^{\mathrm{c}}$ \\
$\mathrm{T} 4=$ Strip relay (T-K) & $897.70^{\mathrm{cd}}$ & $109.47^{\mathrm{bc}}$ \\
\hline $\mathrm{T} 5=$ Row relay (K-T) & $300.02^{\mathrm{a}}$ & $48.12^{\mathrm{a}}$ \\
$\mathrm{T} 6=$ Strip relay (K-T) & $118.07^{\mathrm{a}}$ & $16.50^{\mathrm{a}}$ \\
\hline LSD5\% & 251.36 & 28.81 \\
CV (\%) & 27.24 & 34.53 \\
\hline Values followed by the same letters in the same column on each treatment showed no significant difference influence by LSD5\%.T = Curcuma
\end{tabular}

Values followed by the same letters in the same column on each treatment showed no significant difference influence by LSD $5 \%$. T = Curcuma plant, $\mathrm{K}=$ soybean plants

plant, $K=$ soybean plants 
Table 4. Land equity ratio on different cropping treatment.

\begin{tabular}{lc} 
Treatment on different & LER \\
cropping pattern & \\
$\mathrm{T} 1$ = Row cropping & $1.09^{\mathrm{b}}$ \\
$\mathrm{T} 2$ = Strip cropping & $1.50^{\mathrm{c}}$ \\
\hline $\mathrm{T} 3=$ Row relay (T-K) & $1.09^{\mathrm{b}}$ \\
$\mathrm{T} 4=$ Strip relay (T-K) & $1.23^{\mathrm{bc}}$ \\
\hline $\mathrm{T} 5=$ Row relay (K-T) & $0.57^{\mathrm{a}}$ \\
$\mathrm{T} 6=$ Strip relay (K-T) & $1.17^{\mathrm{b}}$ \\
\hline LSD 5\% & 0.33 \\
CV (\%) & 20.13 \\
\hline
\end{tabular}

Values followed by the same letters in the same column on each treatment showed no significant difference influence based on LSD5\%. LER= Land Equivalent Ratio, $\mathrm{T}=$ Curcuma plant, $\mathrm{K}=$ soybean plants.

\section{References}

1. Hwang JK, Shim JS, Baek NI, Pyun YR. Xanthorrhizol: a potential antibacterial agent from Curcuma xanthorrhiza against Streptococcus mutans. Planta Med 2000:62;196-7.

2. Anggakusuma, Yanti, Lee M, Hwang JK. Estrogenic activity of xanthorrhizol isolated from curcuma xanthorrhiza Roxb. Biol Pharm Bull 2009:32;1892-7.

3. Mangunwardoyo W, Deasywaty, Usia T. Antimicrobial and identification of active compound curcuma xanthorrhiza Roxb. Int J Basic Appl Sci 2012;12:6978 .

4. Oon SF, Nallappan M, Tee TT, et al. Xanthorrhizol: a review of its pharmacological activities and anticancer properties. Cancer Cell Int 2015;15:100.

5. Wardiyati T, Kuswanto, Azizah N. Yield and curcumin content stability of five UB clones of temulawak (Curcuma xanthorriza Rox.). Agrivita 2012:34; 233-23.

6. Suksamrarn A, Eiamong S, Piyachaturawat $\mathrm{P}$, Charoenpiboonsin $\mathrm{J}$. Phenolic diarylheptanoids from Curcumaxanthorrhiza. Phytochemistry 1994:36:1505-8

7. Ruslay S, Abas F, Shaari K, et al. Characterization of the components present in the active fractions of health gingers (Curcumaxanthorrhiza and Zingiber zerumbet) by HPLC-DAD-ESIMS. Food Chemistry 1994:104; 1183-91.

8. Hammerschmidt L, Ola A, Müller WEG, et al. Two new metabolites from the endophytic fungus Xylaria sp. isolated from the medicinal plant Curcuma xanthorrhiza. Tetrahedron Letters 2015: 56;1193-7.

9. Mary HPA, Susheela GK, Jayasree S, et al. Phytochemical characterization and antimicrobial activity of Curcuma xanth-

Table 5. Economics analysis of farming system.

\begin{tabular}{lcccc} 
Different Cropping Pattern & Treatment & Total cost & Total return & Profit R/C Ratio \\
T1 = Row cropping & 134.495 .000 & 273.630 .000 & 139.135 .000 & 2.03 \\
T2 = Strip cropping & 134.605 .000 & 265.545 .000 & 130.940 .500 & 1.97 \\
\hline T3 = Row relay (T-K) & 134.495 .000 & 317.625 .000 & 183.130 .000 & 2.36 \\
T4 = Strip relay (T-K) & 134.605 .000 & 305.620 .000 & 171.015 .500 & 2.27 \\
\hline T5 = Row relay (K-T) & 134.495 .000 & 126.175 .000 & -8.320 .000 & 0.93 \\
T6 = Strip relay (J-T) & 134.605 .000 & 127.015 .000 & -7.589 .500 & 0.94 \\
\hline
\end{tabular}

$\mathrm{R} / \mathrm{C}>1=$ proper to be developed, $\mathrm{R} / \mathrm{C}<1=$ not proper to be developed. $\mathrm{T}=$ Curcuma plants, $\mathrm{K}=$ Soybean plants

orrhiza Roxb. Asian Pacific J Trop Biomed 2012:2;S637-40.

10. Sharma GC, Bajaj BK. Effect of intercropping bell-pepper with ginger on plant parasitic nematode populations and crop yields. Ann Appl Biol 1998;133:199-205.

11. Choudhury AK, Hoque AFME, Firoz ZA, Quayyum MA. Performance of Turmeric-Legume intercropping system. Bangladesh J Agric Res 2000;25: 325-32.

12. Islam F, Karim MR, Shahjahan M, et al. Study on the effect of plant spacing on the production of Turmeric at farmer's field. Asian J Plant Sci 2002;1:616-7.

13. Pandey YR, Karki TB, Paudel GP. Ginger integration in maize based cropping system for increased income in the hills of Nepal. Nepal J Sci Technol 2007;7:19-22

14. Nayak MR, Behera LK, Mishra PJ, Bhola N. Economics and yield performance of some short durat ion fruit and medicinal crops under agrisilvicultural system in rainfed uplands of Odisha. J Appl Nat Sci 2014:6;274-8

15. Khan SA, Hussain M, Noureen N, et al. Yield performance of turmeric varieties intercropped with mulberry plantations. Am Euras J Agric Environ Sci 2015: 15;2076-9.

16. Netsere A, Kufa T. Intercropping of arabica coffee with turmeric (Curcuma longa) and ginger (Zingiber officinale Rose) at Tepi. J Biol Agricult Healthcare 2015:5;65-8.

17. Ishimine $\mathrm{Y}$, Hossain MA, Motomura K, et al. Effects of planting date on emergence, growth and yield of turmeric (Curcuma longa L.) in Okinawa Prefecture, Southern Japan. Jpn J Trop Agric 2014:48;10-6.

18. Kumar B, Gill BS. Growth, yield and quality of turmeric (Curcuma longa L.) as influenced by different planting method, plant density and planting material. J Spices Arom Crops 2010; 19:42-9.

19. Nwaogu EN, Muogbo PC. Effect of ginger- grain legume cropping system and spatial arrangement on soil fertility management and yield of intercropped ginger in the guinea savanna of Nigeria. Int Res J Agric Sci Soil Sci 2015;5:1-7.

20. Singh T, Yadav JP, Singh SB. Effect of spacings and planting of corms on growth and yield of turmeric (Curcuma longa L.) under sodic soils. Narendra Deva J Agric Res 1988:3;165-9.

21. Govind S, Gupta PN, Singh B. Effect of spacings, types and weight of rhizomes on growth and yield of turmeric. Indian Agric 1993;37:249-54.

22. Singh J, Malik YS, Nehra BK, Partap PS. Effect of size of seed rhizomes and plant spacing on growth and yield of turmeric (Curcuma longa L.). Haryana J Hort Sci 2000:29;258-60.

23. Silva NF, Sonnenberg PE, Borges JD, Silva NF. Growth and production of turmeric as a result of mineral fertilizer and planting density. Hort Brasileira 2004;22:61-5.

24. Sakya AT, Purnomo D, Fahruddin F. Penggunaan Ekstrak Teh dan Pupuk Kascing pada Budidaya Caisim (Brassica juncea L.). Jurnal Ilmu Ilmu Tanah dan Agroklimatologi 2009;6:61-8.

25. Hossain MA, Ishimine $Y$, Akamine $H$, Motomura K. Effects of seed rhizome size on growth and yield of turmeric (Curcuma longa L.). Plant Prod Sci 2005;8:86-94.

26. Grookston RK, Hill DS. Grain yield and land equivalent ratios from intercropping corn and soybean in Minnesota. Agron J 1979;71:41-4.

27. Odango JCW, Veresoglo DS, Sficas AG. Effects of population density, nitrogen fertilization and inocculation on the yield of intercropped maize and soybean. Field Crop 1990:43-055619.

28. Hayder G, Mumtaz SS, Khan A, Khan S. Maize and soybean intercropping under various levels of soybean seed rates. Asian J Plant Sci 2003;2:339-41.

29. Chatarina TS. Response of maize in monoculture system with nuts intercropping to the supplies of $\mathrm{N}$ nutrient and the value of land equality in Dryland. Ganec Swara 2009;3:5. 